\title{
Future in the Past: Azorella glabra Wedd. as a Source of New Natural Compounds with Antiproliferative and Cytotoxic Activity on Multiple Myeloma Cells
}

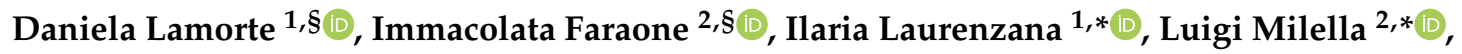 \\ Stefania Trino ${ }^{1}$, Luciana De Luca ${ }^{1}{ }^{1}$, Luigi Del Vecchio ${ }^{3,+}$, Maria Francesca Armentano ${ }^{2}{ }^{(1)}$, \\ Chiara Sinisgalli ${ }^{2}$, Lucia Chiummiento ${ }^{2} \mathbb{D}$, Daniela Russo ${ }^{2}$, Faustino Bisaccia ${ }^{2}$, \\ Pellegrino Musto ${ }^{4, \ddagger}$ and Antonella Caivano ${ }^{1, \ddagger}$ \\ 1 Laboratory of Preclinical and Translational Research, IRCCS “Referral Cancer Center of Basilicata” (CROB), \\ 85028 Rionero in Vulture, PZ, Italy; daniela.lamorte@crob.it (D.L.); stefania.trino@gmail.com (S.T.); \\ luciana.deluca@crob.it (L.D.L.); antonella.caivano@crob.it (A.C.) \\ 2 Department of Science, University of Basilicata, 85100 Potenza, Italy; immafaraone88@gmail.com (I.F.); \\ mariafrancesca.armentano@unibas.it (M.F.A.); chiara.sinisgalli@gmail.com (C.S.); \\ lucia.chiummiento@unibas.it (L.C.); daniela.russo@unibas.it (D.R.); faustino.bisaccia@unibas.it (F.B.) \\ 3 Department of Molecular Medicine and Medical Biotechnology, Federico II University, 80131 Naples, Italy \\ 4 Hematology and Stem Cell Transplantation Unit, IRCCS “Referral Cancer Center of Basilicata” (CROB), \\ 85028 Rionero in Vulture, PZ, Italy; pellegrino.musto@crob.it \\ * Correspondence: ilaria.laurenzana@crob.it (I.L.); luigi.milella@unibas.it (L.M.); \\ Tel.: +39-0972-726-528 (I.L.); +39-0971-205-525 (L.M.) \\ $\dagger \quad$ Prof. Luigi Del Vecchio died on 16 August 2018. \\ $\ddagger$ These are co-last authors. \\ $\S$ These authors contributed equally to the work.
}

Received: 26 September 2018; Accepted: 24 October 2018; Published: 26 October 2018

\begin{abstract}
Multiple myeloma (MM) is the second most common hematologic malignancy and, although the development of novel agents has improved survival of patients, to date, it remains incurable. Thus, newer and more effective therapeutic strategies against this malignancy are necessary. Plant extracts play an important role in anti-tumor drug discovery. For this reason, in the investigation of novel natural anti-MM agents, we evaluated the phytochemical profiles, in vitro antioxidant activity, and effects on MM cells of Azorella glabra (AG) Wedd. Total polyphenols (TPC), flavonoids (TFC), and terpenoids (TTeC) contents were different among samples and the richest fractions in polyphenols demonstrated a higher antioxidant activity in in vitro assays. Some fractions showed a dose and time dependent anti-proliferative activity on $\mathrm{MM}$ cells. The chloroform fraction $\left(\mathrm{CHCl}_{3}\right)$ showed major effects in terms of reduction of cell viability, induction of apoptosis, and cell cycle arrest on MM cells. The apoptosis induction was also confirmed by the activation of caspase- 3 . Importantly, the $\mathrm{CHCl}_{3}$ fraction exhibited a negligible effect on the viability of healthy cells. These results encourage further investigations on AG extracts to identify specific bioactive compounds and to define their potential applications in MM.
\end{abstract}

Keywords: Azorella glabra Wedd.; phytochemicals; multiple myeloma; cytotoxic effect; apoptosis; cell cycle arrest

\section{Introduction}

Multiple myeloma (MM) is still an incurable hematologic malignancy characterized by a clonal growth of plasma cells in the bone marrow [1]. MM is the second most frequent hematologic 
malignancy [2], with an incidence rate of 6.2 per $1 \times 10^{5}$ individuals [3], and it mainly affects individuals with a median age of 65-70 years at diagnosis [4]. This neoplasm is associated with a five year overall survival of $48.5 \%$ [5]. Although hematopoietic stem cell transplantation and novel targeted agents, such as proteasome inhibitors [6,7], monoclonal antibodies [8,9], immunomodulatory drugs [10], check-point inhibitors [11], and epigenetic modulators [12], have significantly achieved lasting remission and increased survival rates [13], most patients relapse, develop resistance, and eventually die because of refractory disease [14]. All these issues highlight the need to investigate newer therapeutic targets $[15,16]$ to improve patient outcomes.

Plant extracts play an important role as a new therapeutic strategy in cancer [2] because they include various types of metabolites with different chemical structures and bioactivities. In fact, by synergistic and/or additive effects [17-19] they target different pathways in malignant cells, such as proliferation, differentiation, and apoptosis [20]. Furthermore, plant extracts have a favorable profile of absorption and metabolism and show no or low toxicity towards normal cells. The biological activities of plant extracts are mainly due to their content in polyphenols, flavonoids, and terpenoids. Numerous studies showed that polyphenols, generally recognized as antioxidants, possess anticancer and pro-apoptosis properties [21,22]. Other studies reported the potential clinical applications of flavonoids for their well-known protective and therapeutic effects against cancer, cardiovascular, and neurodegenerative diseases [23], and of terpenoids, for their anti-cancer, anti-malarial, anti-inflammatory, anti-bacterial, and anti-viral activities [24].

The combination of plant extracts with anti-cancer drugs may offer a significant advantage for therapeutic efficacy by sensitizing malignant cells to drugs and overcoming drug-induced resistance in cancer [25]. For all these reasons, a significant number of compounds isolated from plants are still used nowadays in cancer clinical practice in combination with other drugs [26], also against hematologic malignancies [27-31].

During the last years, research has focused on novel plant extract metabolites as possible anti-tumor agents on various types of cancer, including hematologic malignancies; recent work demonstrated the cytotoxic effects of various species of Centaurea genus against various cancer cell lines, including a panel of hematologic malignancies cells, such as pre-B-ALL, MM, and acute promyelocytic leukemia (APL) [32]. Kabeel et al. (2018) showed the anti-leukemic effects of a mixture of four water plant extracts (Arctium lappa, Ulmus rubra, Rumex acetosella, and Rheum palmatum) in a leukemic rat model [33]. In addition, it was previously reported that Azorella compacta methanolic extract induced apoptosis in leukemia cells [34].

Furthermore, in the past decades, plant extracts have attracted much attention also in the field of MM. Shammas et al. (2006) demonstrated that epigallocatechin-3-gallate, an abundant polyphenol in green tea, possesses anti-MM effects in in vitro and in vivo assays [35]. More recently, Wang and colleagues (2015) found that aloperine, a natural alkaloid isolated from the herb, Sophora alopecuroides, inhibited MM cell growth in in vitro and in vivo assays; reduced bone lesions in a human MM xenograft mouse model, increasing their survival; and showed a synergistic inhibitory effect on MM growth with bortezomib [36]. In addition, the in vitro anti-MM effects of Punica granatum extracts were demonstrated [20].

In the present study, for the first time and to the best of our knowledge, the phytochemicals, the in vitro antioxidant properties, and the effects on MM cells of Azorella glabra (AG) aerial parts, a plant belonging to the Apiaceae family [37], have been investigated.

\section{Results}

\subsection{Extraction Yield and Total Polyphenol (TPC), Flavonoid (TFC), and Terpenoid (TTeC) Content of AG} Extract and Fractions

The aerial parts of AG were dried at room temperature and extracted using $96 \%$ ethanol $(\mathrm{EtOH})$ by dynamic maceration with an extraction yield of $9.01 \%$. Then, the crude EtOH extract, named with acronym $\mathrm{EtOH}$, was separated based on the affinity solvent by liquid/liquid extraction using an 
increasing solvent polarity obtaining the fractions named with following acronyms: Hex for $n$-hexane solvent, $\mathrm{CHCl}_{3}$ for chloroform solvent, EtAc for ethyl acetate solvent, $\mathrm{BuOH}$ for $n$-butanol solvent and $\mathrm{H}_{2} \mathrm{O}$ for water solvent. The $\mathrm{Hex}$ and $\mathrm{CHCl}_{3}$ fractions showed the highest extraction yield $(44.50 \%$ and $31.52 \%$, respectively); instead, the EtAc and $\mathrm{BuOH}$ fractions demonstrated the lower extraction yields (2.23\% and 5.66\%, respectively) (Figure 1 ).

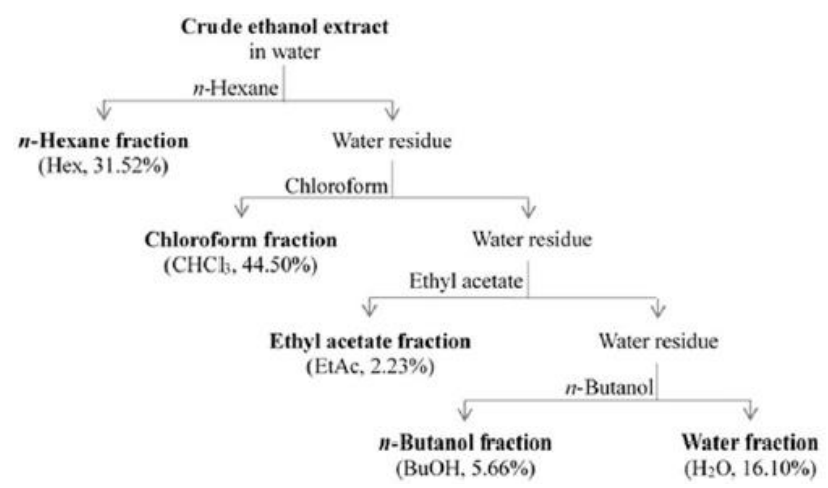

Figure 1. Schematic representation of liquid/liquid extraction of AG aerial parts.

Three different in vitro colorimetric methods were used for the determination of the phytochemical profiles of each fraction in terms of TPC, TFC, and TTeC (Figure 2). Samples displayed quantitative differences in TPC value, with a mean value of $72.52 \mathrm{mg}$ of gallic acid equivalents per gram of dried sample (mg GAE/g). The EtAc and $\mathrm{BuOH}$ fractions showed a higher TPC than other fractions (143.60 \pm 0.40 and $128.14 \pm 0.74 \mathrm{mg} \mathrm{GAE} / \mathrm{g}$, respectively). In addition, flavonoids, a class of polyphenols with several biological properties [38], have been measured in AG samples. TFC showed a mean value of $264.13 \mathrm{mg}$ of quercetin equivalents per gram of dried sample (mgQE/g). The EtOH extract, the EtAc, and $\mathrm{BuOH}$ fractions showed higher TFC (764.86 \pm 16.76, $354.97 \pm 22.05$, and $209.73 \pm 5.56 \mathrm{mg} \mathrm{QE} / \mathrm{g}$, respectively) than other fractions. Moreover, $\mathrm{TTeC}$ was also determined. The $\mathrm{CHCl}_{3}$ and $\mathrm{Hex}$ fractions and the $\mathrm{EtOH}$ extract exhibited higher values (733.51 \pm 9.42 , $421.77 \pm 41.46$, and $405.44 \pm 29.33 \mathrm{mg} \mathrm{LE} / \mathrm{g}$, respectively) than the mean value of $338.38 \mathrm{mg}$ of linalool equivalents per gram of dried sample (mg LE/g).

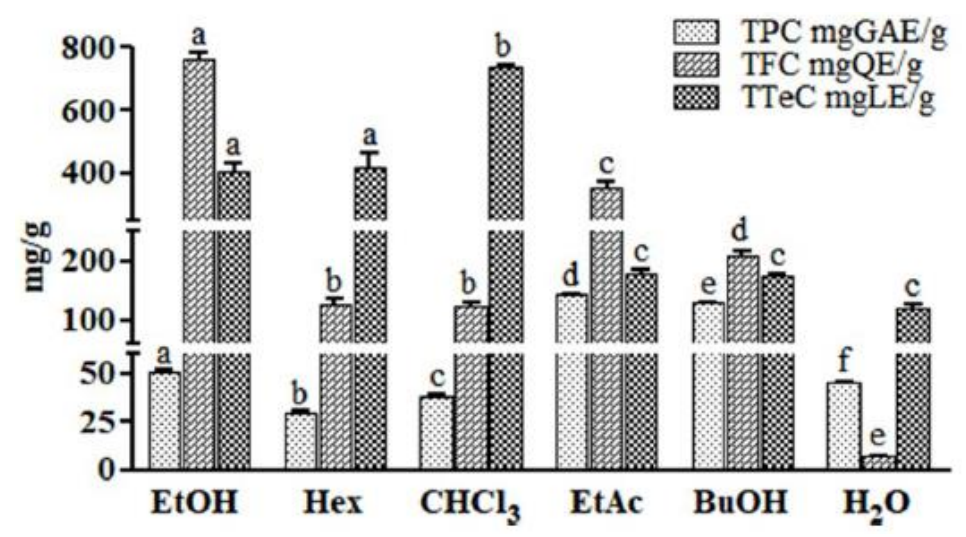

Figure 2. Total polyphenol content (TPC), total flavonoid content (TFC), and total terpenoid content (TTeC) of AG samples. Results were expressed as mean \pm standard deviation of triplicate determinations in $\mathrm{mg}$ of gallic acid equivalents per gram of dried sample ( $\mathrm{mg} \mathrm{GAE} / \mathrm{g}$ ), in $\mathrm{mg}$ of quercetin equivalents per gram of dried sample ( $\mathrm{mg} \mathrm{QE} / \mathrm{g}$ ), and in mg of linalool equivalents per gram of dried sample (mg LE/g). For each test, the values with identical letters are not significantly different at the $p<0.05$ level, $95 \%$ confidence limit, according to one-way analysis of variance (ANOVA). Samples are ethanol extract $(\mathrm{EtOH})$ and $n$-hexane $(\mathrm{Hex})$, chloroform $\left(\mathrm{CHCl}_{3}\right)$, ethyl acetate $(\mathrm{EtAc}), n$-butanol $(\mathrm{BuOH})$, and water $\left(\mathrm{H}_{2} \mathrm{O}\right)$ fractions of $\mathrm{AG}$ aerial parts. 


\subsection{Radical-Scavenging Activity}

The antioxidant activity of AG samples was tested by the determination of the radical scavenging activity by synthetic $2.2^{\prime}$-azino-bis(3-ethylbenzothiazoline-6-sulfonic acid) (ABTS) and physiological superoxide anion (SO) and nitric oxide (NO) radicals (Table 1 ).

Table 1. Results of ABTS, super oxide (SO), and nitric oxide (NO) scavenging activity of AG samples.

\begin{tabular}{cccc}
\hline Samples & ABTS $(\mathbf{m g T E} / \mathbf{g})$ & SO $\left(\mathbf{I C}_{25} \mathbf{~ m g} / \mathbf{m L}\right)$ & NO $\left(\mathbf{I C}_{\mathbf{2 5}} \mathbf{~ m g} / \mathbf{m L}\right)$ \\
\hline EtOH extract & $76.83 \pm 1.23^{\mathrm{a}}$ & $2.59 \pm 0.11^{\mathrm{a}}$ & $/$ \\
Hex fraction & $/$ & $/$ & $/$ \\
$\mathrm{CHCl}_{3}$ fraction & $32.08 \pm 0.02^{\mathrm{b}}$ & $0.47 \pm 0.02^{\mathrm{b}}$ & $/$ \\
EtAc fraction & $282.26 \pm 9.53^{\mathrm{c}}$ & $0.12 \pm 0.01^{\mathrm{c}}$ & $/$ \\
$\mathrm{BuOH}$ fraction & $206.65 \pm 7.28^{\mathrm{d}}$ & $0.20 \pm 0.01^{\mathrm{c}}$ & $9.13 \pm 0.09^{\mathrm{a}}$ \\
$\mathrm{H}_{2} \mathrm{O}$ fraction & $65.09 \pm 0.40^{\mathrm{a}}$ & $0.37 \pm 0.02^{\mathrm{b}}$ & $8.94 \pm 0.07^{\mathrm{b}}$
\end{tabular}

Data are expressed as means \pm standard deviation from three experiments; $\mathrm{mg} \mathrm{TE} / \mathrm{g}=\mathrm{mg}$ of trolox equivalents per gram of dried sample; $\mathrm{IC}_{25} \mathrm{mg} / \mathrm{mL}=$ concentration of the samples required to inhibit the activity of the radical by $25 \%$; different superscripts in the same row indicate significant difference $(p<0.05)$; / = below the detection limit of the assay. Samples are ethanol extract $(\mathrm{EtOH})$ and n-hexane (Hex), chloroform $\left(\mathrm{CHCl}_{3}\right)$, ethyl acetate $(\mathrm{EtAc})$, n-butanol $(\mathrm{BuOH})$, and water $\left(\mathrm{H}_{2} \mathrm{O}\right)$ fractions of $\mathrm{AG}$ aerial parts.

The EtAc fraction showed the highest radical scavenging-activity in the ABTS assay with a value of $282.26 \pm 9.53 \mathrm{mg} \mathrm{TE} / \mathrm{g}$, followed by the $\mathrm{BuOH}$ fraction; instead, the Hex fraction was inactive.

The ability of samples to scavenge biological $\mathrm{SO}$ and $\mathrm{NO}$ was expressed as $\mathrm{IC}_{25}$, and results were compared with ascorbic acid. All samples, except for Hex fraction, caused a dose-dependent inhibition in the $\mathrm{SO}$ assay. In particular, the EtAc and $\mathrm{BuOH}$ fractions showed higher activity $\left(\mathrm{IC}_{25}\right.$ of $0.12 \pm 0.01$ and $0.20 \pm 0.01 \mathrm{mg} / \mathrm{mL}$, respectively) than ascorbic acid $\left(\mathrm{IC}_{25} \mathrm{of} 0.26 \pm 0.02 \mathrm{mg} / \mathrm{mL}\right)$. The scavenging ability against $\mathrm{NO}$ was only reported by the $\mathrm{BuOH}$ and $\mathrm{H}_{2} \mathrm{O}$ fractions, with a dose-dependent inhibition with higher values of ascorbic acid ( $\mathrm{IC}_{25} 4.78 \pm 0.09 \mathrm{mg} / \mathrm{mL}$ ).

The linear correlation coefficient $(r)$ was calculated by the Pearson test. The results showed a strong correlation between polyphenols and antioxidant activity. In fact, the highest correlation was found between the TPC and radical-scavenging activity against ABTS and super oxide radicals $\left(\mathrm{r}_{\mathrm{TPC} / \mathrm{ABTS}}=0.99\right.$ and $\left.\mathrm{r}_{\mathrm{TPC} / \mathrm{SO}}=0.92\right)$. Instead, the terpenoids were less involved in the scavenging-activity $(\mathrm{r}<0)$.

The results obtained by ABTS, SO, and NO assays together with TPC have been integrated with each other by calculating the relative antioxidant capacity index (RACI) [39]. The EtAc and BuOH fractions had the highest RACI values (1.00 and 0.98, respectively) (Figure 3). The Hex fraction showed the lowest index (-0.88). In particular, the RACI value seems to be related to the high TPC of the EtAc and $\mathrm{BuOH}$ fractions.

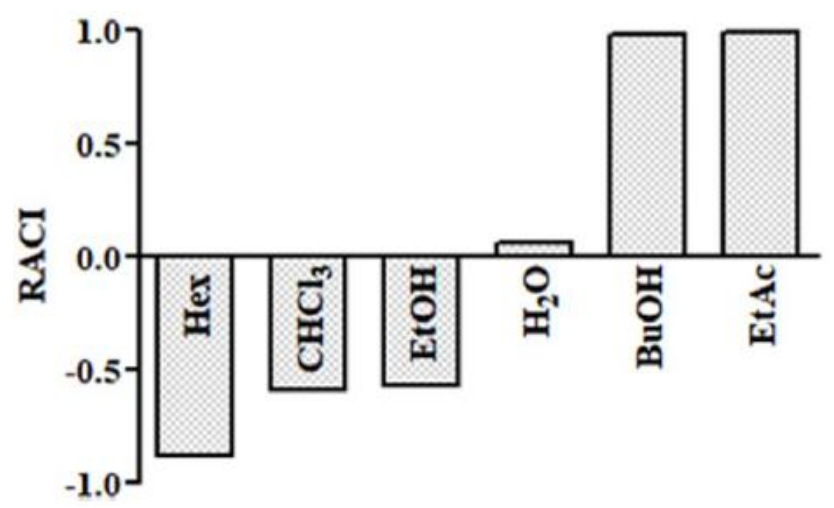

Figure 3. Relative antioxidant capacity index (RACI) of AG samples. Samples are ethanol extract $(\mathrm{EtOH})$ and $n$-hexane $(\mathrm{Hex})$, chloroform $\left(\mathrm{CHCl}_{3}\right)$, ethyl acetate $(\mathrm{EtAc}), n$-butanol $(\mathrm{BuOH})$, and water $\left(\mathrm{H}_{2} \mathrm{O}\right)$ fractions of $\mathrm{AG}$ aerial parts. 


\subsection{Viability Analysis of MM and Healthy Cells Treated with AG Samples}

We treated MM cell lines, RPMI8226, SKMM1, and MM1S, with six different AG samples or with dimethyl sulfoxide (DMSO) vehicle control at different concentrations (10-150 $\mu \mathrm{g} / \mathrm{mL}$ ) for 24, 48, and $72 \mathrm{~h}$ (Figure 4). Viability test showed that most of samples, except for the EtOH extract, $\mathrm{BuOH}$, and $\mathrm{H}_{2} \mathrm{O}$ fractions, exhibited a dose and time dependent anti-proliferative effect on MM cells. In particular, $\mathrm{AG} \mathrm{CHCl}_{3}$ fraction was the most active one on all $\mathrm{MM}$ cell lines and its effect was observed already at $24 \mathrm{~h}$ of treatment with the lowest concentration $(10 \mu \mathrm{g} / \mathrm{mL})$.

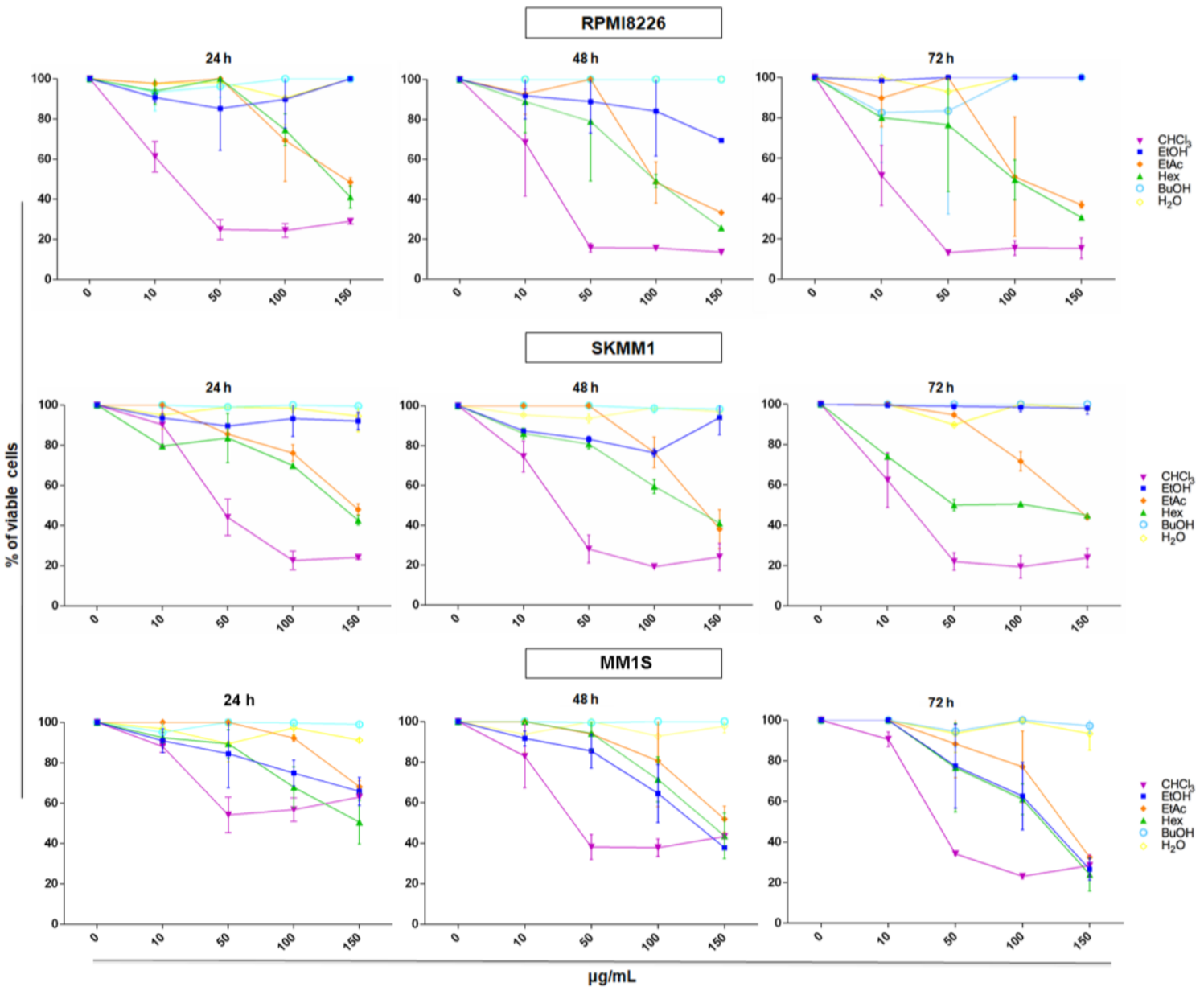

Figure 4. Viability assay of RPMI8226, SKMM1, and MM1S cells after treatment with AG samples at different concentrations $(10,50,100$, and $150 \mu \mathrm{g} / \mathrm{mL})$ for 24, 48, and $72 \mathrm{~h}$. Results are expressed as percent of cell viability normalized to DMSO-treated control cells. The line-graphs represent the average with standard deviation from three independent experiments. Samples are ethanol extract $(\mathrm{EtOH})$ and $n$-hexane (Hex), chloroform $\left(\mathrm{CHCl}_{3}\right)$, ethyl acetate $(\mathrm{EtAc}), n$-butanol $(\mathrm{BuOH})$, and water $\left(\mathrm{H}_{2} \mathrm{O}\right)$ fractions of $\mathrm{AG}$ aerial parts.

We also calculated the concentration of the $\mathrm{CHCl}_{3}$ fraction that inhibited $\mathrm{MM}$ cell growth of $50 \%$ ( $\mathrm{EC}_{50}$; Table 2). $\mathrm{EC}_{50}$ value was reduced over the time in all the MM tested lines. After $24 \mathrm{~h}$ of treatment, we obtained $\mathrm{EC}_{50}$ values of $16.74,44.76$, and $165.90 \mu \mathrm{g} / \mathrm{mL}$ for RPMI8226, SKMM1, and MM1S cells, respectively. 


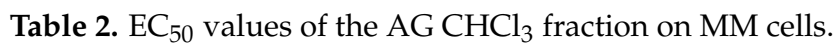

\begin{tabular}{cccc}
\hline MM Cell Lines & $\mathbf{2 4} \mathbf{h ~} \boldsymbol{\mu g} / \mathbf{m L}$ & $\mathbf{4 8 ~ h ~} \mathbf{g g} / \mathbf{m L}$ & $\mathbf{7 2} \mathbf{h ~} \boldsymbol{g g} / \mathbf{m L}$ \\
\hline RPMI8226 & 16.74 & 17.38 & 10.03 \\
SKMM1 & 44.76 & 25.75 & 16.52 \\
MM1S & 165.90 & 53.02 & 39.63 \\
\hline
\end{tabular}

Furthermore, to exclude any toxic effects on healthy cells, we treated peripheral blood mononuclear cells isolated from five healthy donors (HD-PBMCs) with different concentrations $(10-150 \mu \mathrm{g} / \mathrm{mL})$ of $\mathrm{AG} \mathrm{CHCl}{ }_{3}$ fraction for 24 and $48 \mathrm{~h}$. Interestingly, the $\mathrm{AG} \mathrm{CHCl}_{3}$ fraction had negligible effect on HD-PBMCs (Figure 5).

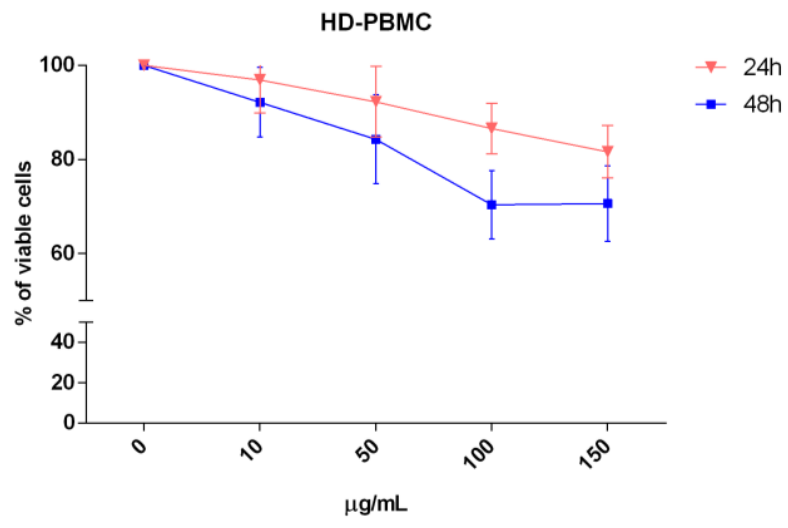

Figure 5. Analysis of five HD-PBMC viability after treatment with different concentrations (10, 50, 100 , and $150 \mu \mathrm{g} / \mathrm{mL}$ ) of $\mathrm{AG} \mathrm{CHCl}_{3}$ fraction for 24 and $48 \mathrm{~h}$. Results are expressed as percent of cell viability normalized to DMSO-treated control cells. The line-graphs represent the average with standard deviation from five healthy subjects.

\subsection{Evaluation of Apoptosis in MM Cells Treated with $\mathrm{AG} \mathrm{CHCl}_{3}$ Fraction}

To investigate the anti-proliferative effect induced in cells treated with the $\mathrm{AG} \mathrm{CHCl}_{3}$ fraction, we performed the apoptosis assay on MM cells using a concentration of $50 \mu \mathrm{g} / \mathrm{mL}$. The $\mathrm{AG} \mathrm{CHCl}_{3}$ fraction treatment for 24 and $48 \mathrm{~h}$ induced a significant increase of apoptosis in MM cells with respect to their control in a time dependent manner (Figure 6A-F). In particular, the percentage of apoptotic cells increased from $53.19 \%$ at $24 \mathrm{~h}$ in the $\mathrm{CHCl}_{3}$ fraction treated cells with respect to DMSO control to $76.99 \%$ at $48 \mathrm{~h}$ for RPMI8226 cells (Figure $6 \mathrm{~A}, \mathrm{~B}$ ), from $31.80 \%$ at $24 \mathrm{~h}$ to $63.15 \%$ at $48 \mathrm{~h}$ for SKMM1 cells (Figure 6C,D), and from $64.35 \%$ at $24 \mathrm{~h}$ to $86.25 \%$ at $48 \mathrm{~h}$ for MM1S cells (Figure $6 \mathrm{E}, \mathrm{F}$ ).

Moreover, apoptosis was also evaluated by western blot analysis in RPMI8226 cells (Figure 6G,I). In particular, the presence of the cleaved form of the caspase- 3 substrate, the poly-ADP ribose polymerase (cleaved PARP-1), and the expression level of Bcl-2 were examined. We observed a significant activation of caspase-3 in MM cells treated for $24 \mathrm{~h}$ with $50 \mu \mathrm{g} / \mathrm{mL}$ of $\mathrm{AG} \mathrm{CHCl}_{3}$ fraction compared to the control, detectable by the increase of cleaved PARP-1 (Figure 6G). Instead, the expression of Bcl-2 was the same in MM treated and control cells (Figure $6 \mathrm{H}$ ). 

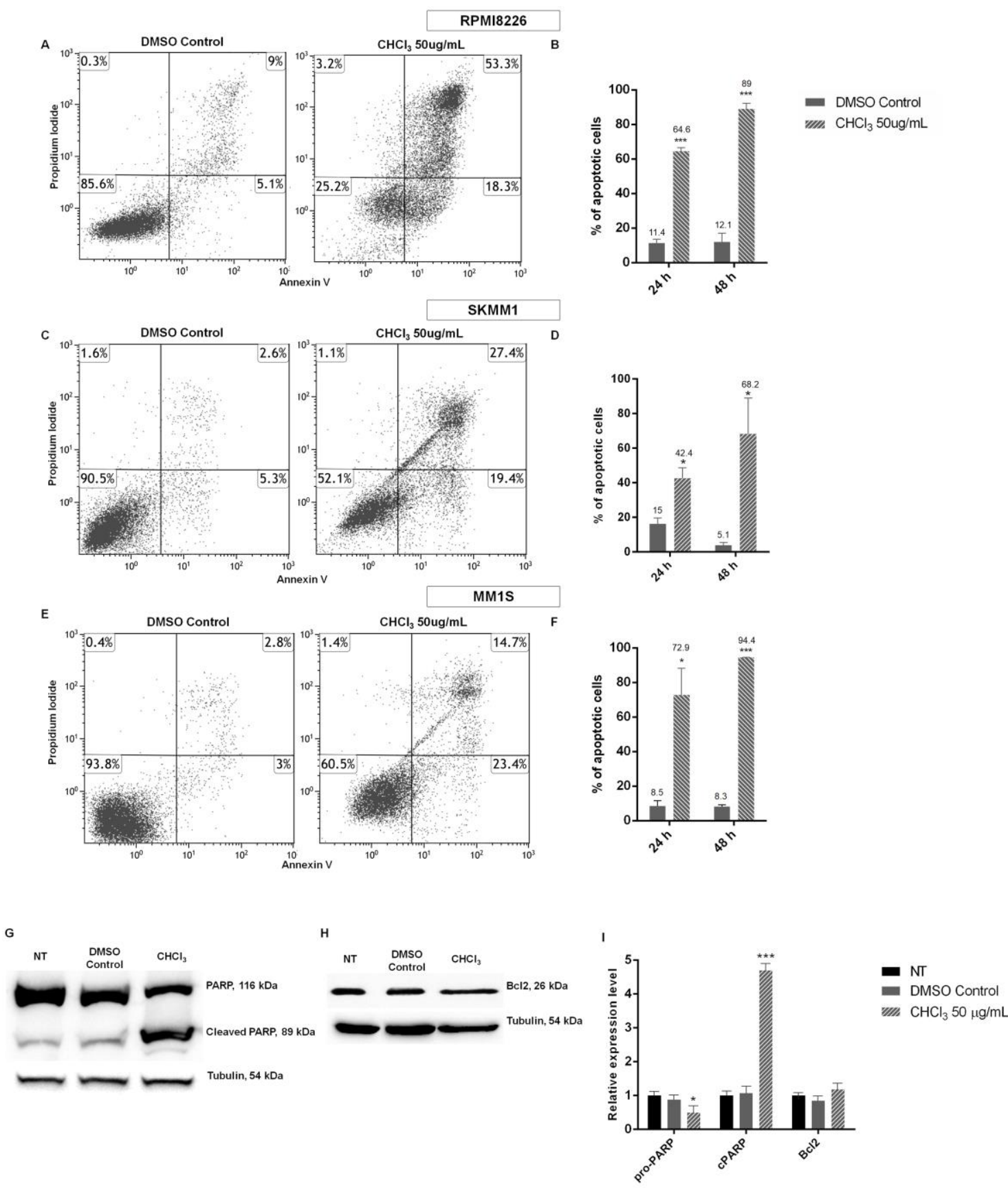

Figure 6. Cytofluorimetric evaluation of apoptosis/necrosis of RPMI8226 (A,B), SKMM1 (C,D), and

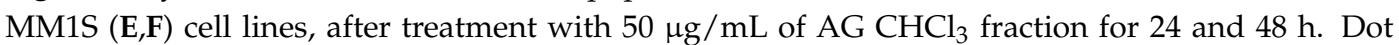
plots (A,C,E) show a single representative experiment after $24 \mathrm{~h}$ of treatment; the bar-graphs $(\mathbf{B}, \mathbf{D}, \mathbf{F})$ represent the average of percent of apoptosis, obtained from the sum of early and late apoptosis, of three independent experiments with standard deviation $\left.{ }^{*} p<0.05,{ }^{* * *} p<0.001\right)$. Western blot analysis of the AG $\mathrm{CHCl}_{3}$ fraction on the expression of PARP-1 $(\mathbf{G})$, cleaved PARP $(\mathbf{G})$, and Bcl2 $(\mathbf{H})$ in RPMI8226 cells treated with $50 \mu \mathrm{g} / \mathrm{mL}$ of $\mathrm{AG} \mathrm{CHCl}_{3}$ fraction for $24 \mathrm{~h}$. Tubulin was used as a protein loading control. The bar-graphs (I) are representative of three independent experiments. Statistical analysis was carried out by a paired two-tailed Student's $t$-test $\left({ }^{*} p<0.05,{ }^{* * *} p<0.001, n=3\right)$. Data were represented as mean \pm standard error of the mean.

\subsection{Cell Cycle Analysis in MM Cells Treated with $\mathrm{AG} \mathrm{CHCl}_{3}$ Fraction}

Cell cycle cytofluorimetric analysis of $\mathrm{MM}$ cells treated with $50 \mu \mathrm{g} / \mathrm{mL}$ of $\mathrm{AG} \mathrm{CHCl}_{3}$ fraction showed a G0/G1-phase arrest with respect to control in a time dependent manner (Figure 7B,D,F). 
In particular, the number of RPMI8226 treated cells in the G0/G1 phase significantly increased from $34.50 \%$ to $53.82 \%$ and from $24.00 \%$ to $60.00 \%$ after 24 and $48 \mathrm{~h}$, respectively.

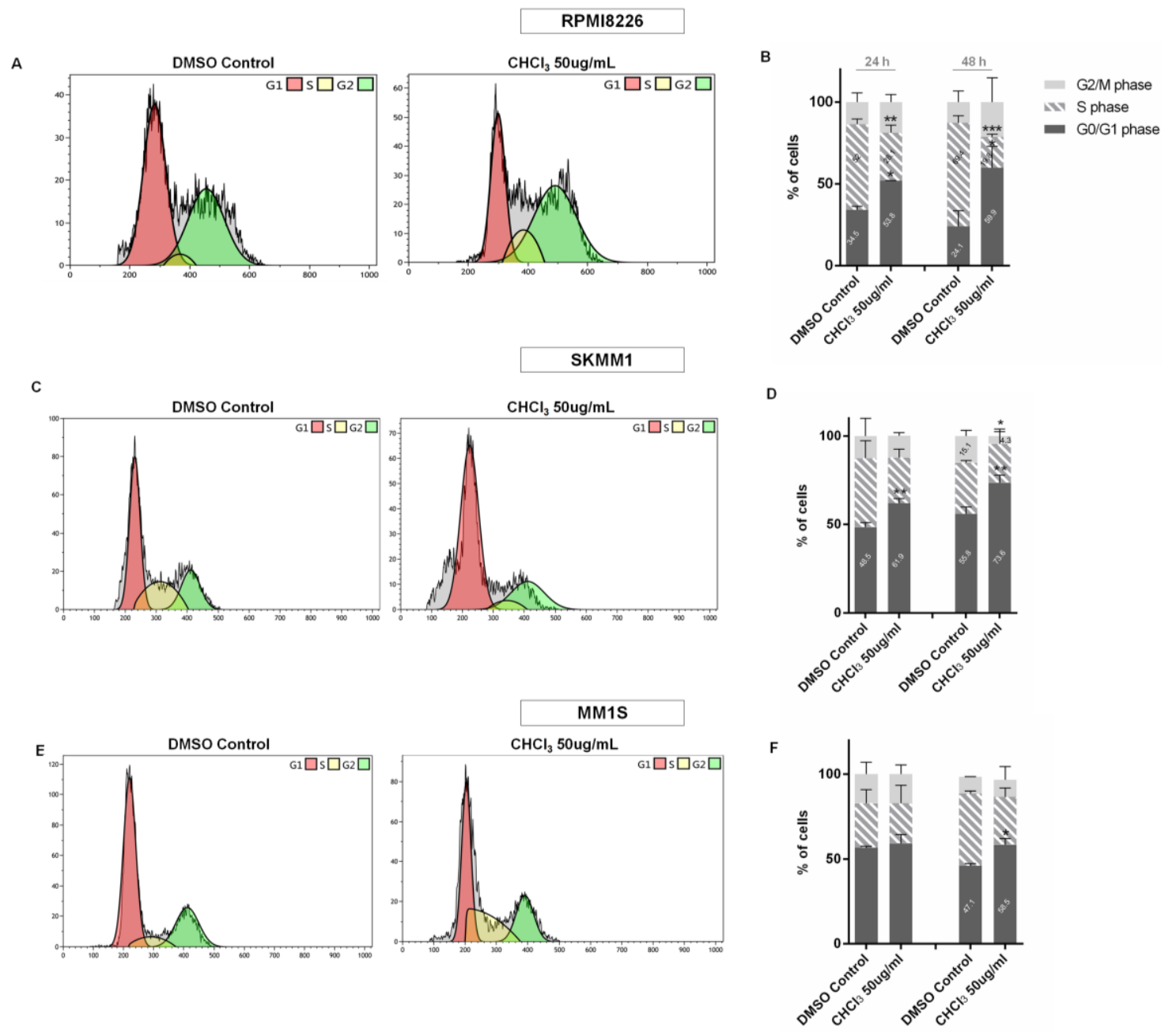

Figure 7. Cytofluorimetric evaluation of cell cycle on RPMI8226, SKMM1, and MM1S cell lines, at $50 \mu \mathrm{g} / \mathrm{mL}$ of $\mathrm{AG} \mathrm{CHCl}_{3}$ fraction for 24 and $48 \mathrm{~h}$. Cell cycle histograms (A,C,E) show a single representative experiment after $24 \mathrm{~h}$ of treatment; the bar-graphs $(\mathbf{B}, \mathbf{D}, \mathbf{F})$ represent the average of three independent experiments with standard deviation $\left({ }^{*} p<0.05,{ }^{* *} p<0.01\right.$, $\left.{ }^{* * *} p<0.001\right)$.

Moreover, a significant decrease of RPMI8226 treated cells in the $S$ phase was observed at 24 and $48 \mathrm{~h}(28.1 \%$ and $19.8 \%$, respectively) (Figure $7 \mathrm{~A}, \mathrm{~B})$.

A similar result was observed for SKMM1 cells: The percentage of cells in the G0/G1 phase increased from $48.46 \%$ to $61.88 \%$ and from $55.83 \%$ to $73.55 \%$ after 24 and $48 \mathrm{~h}$ of treatment, respectively.

In addition, after $48 \mathrm{~h}$ of treatment, the number of cells at the G2/M phase decreased from $15.10 \%$ to $4.34 \%$ for the control and SKMM1 cells, respectively (Figure 7C,D). For MM1S, we observed a significant increase of cells in the G0/G1 phase from $47.08 \%$ to $58.50 \%(p<0.05)$ after $48 \mathrm{~h}$ of treatment (Figure 7E,F).

\subsection{Cell Migration Assay in RPMI8226 Cells Treated with $\mathrm{AG} \mathrm{CHCl}_{3}$ Fraction}

The effects of the $\mathrm{AG} \mathrm{CHCl}_{3}$ fraction on the MM cell migration were investigated in RPMI8226 cells using a Transwell assay. Data showed that the $\mathrm{AG} \mathrm{CHCl}_{3}$ fraction reduced the cell migration rate. The percentage of migrated RPMI8226 treated cells was 54\% with respect to the DMSO control, indicating that $\mathrm{AG} \mathrm{CHCl}_{3}$ induced a significant decrease of $\mathrm{MM}$ cell migration $(p=0.01)$ (Figure 8). 


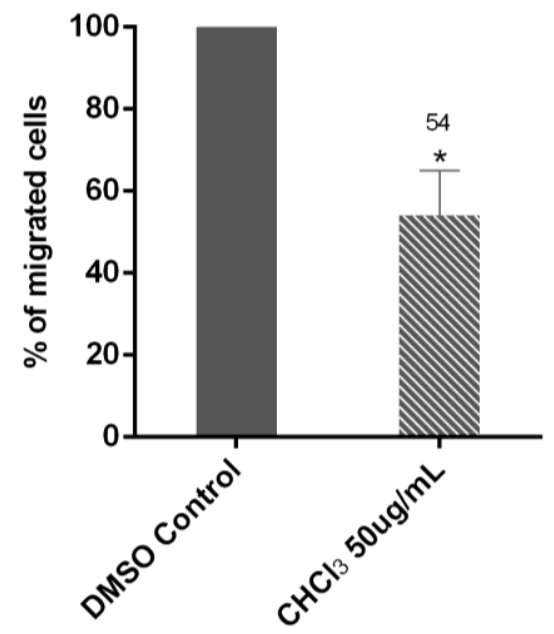

Figure 8. Transwell migration assays of RPMI8226 cells performed after treatment with $50 \mu \mathrm{g} / \mathrm{mL}$ of $\mathrm{AG} \mathrm{CHCl}_{3}$ fraction and with DMSO control. Migrated cells were counted after $24 \mathrm{~h}$ of incubation. The bar-graphs represent the average of three independent experiments with standard deviation $\left({ }^{*} p<0.05\right)$.

\subsection{ROS Production and Mitochondria Membrane Potential $\left(\Delta \Psi_{m}\right)$}

The effects of the AG $\mathrm{CHCl}_{3}$ fraction on the intracellular redox status were investigated in RPMI8226 cells by the determination of the levels of ROS production. Data showed that the AG $\mathrm{CHCl}_{3}$ fraction did not significantly affect ROS formation at $50 \mathrm{\mu g} / \mathrm{mL}$ as compared with control cells (Figure 9A).
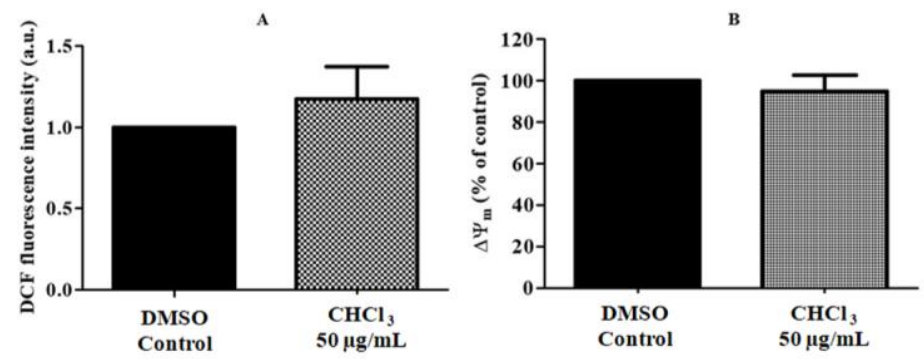

Figure 9. Evaluation of the intracellular ROS levels (A) and of $\Delta \Psi_{\mathrm{m}}$ depolarization (B) of RPMI8226 cells treated with $50 \mu \mathrm{g} / \mathrm{mL}$ of $\mathrm{AG} \mathrm{CHCl}_{3}$ fraction. The values are means \pm standard error of three replicates from three independent experiments.

The $\Delta \Psi_{m}$ was evaluated by the cation fluorescent probe, tetramethylrhodamine methyl ester (TMRM), to verify whether the ROS formation in RPMI8226 cells could be fitted with the changes or loss in $\Delta \Psi_{m}$. RPMI8226 cells exposed to $50 \mu \mathrm{g} / \mathrm{mL}$ of the $\mathrm{AG} \mathrm{CHCl}_{3}$ fraction for $6 \mathrm{~h}$ did not show any significant difference compared to the control (Figure 9B).

\section{Discussion}

Natural products have been the cornerstones of anticancer pharmacology for many years and a significant number of compounds isolated from plants and microorganism are still tested nowadays for their anti-cancer activity [40-44], including hematologic malignancies [2,29,45].

In the present work, we suggest a sort of "future in the past" as we believe that, in the modern era of medicine engineering, natural-derived compounds, and plant extracts specifically, should continue to be considered one of the most important sources of natural and ideal anti-cancer drugs.

The biological activities of plant extracts are mainly due to their contents of polyphenols, flavonoids, and terpenoids. Numerous studies showed that these classes of compounds possess antioxidants, anti-inflammatory, and anticancer properties [21,24]. In this context, we reported that TPC, TFC, and 
$\mathrm{TTeC}$ of EtOH AG extract and its fractions differed among samples. These differences are congruent based on varying polarities of the used solvents. Fractions obtained with high polarity solvents reported the highest TPC and TFC, indicating that the majority of polyphenolic compounds in the AG samples could be polar compounds. At the same time, the highest total TTeC was reported in not polar $\mathrm{CHCl}_{3}$ and Hex fractions [46]. We found a correlation between TPC and antioxidant activity. Instead, $\mathrm{TTeC}$ was less involved in the scavenging activity.

The cytotoxic and apoptotic effects of different phyto-extracts on MM cells were recently documented in many studies [20,47-49]. In the present work, some fractions, except for the EtOH extract and $\mathrm{BuOH}$ and $\mathrm{H}_{2} \mathrm{O}$ fractions, showed a dose and time dependent anti-proliferative effect on the MM cells. Among all, $\mathrm{AG} \mathrm{CHCl}_{3}$ and Hex fractions resulted in the most active. Probably, their cytotoxic effect could be due to the greater content of TTeC. In fact, $\mathrm{AG} \mathrm{CHCl}_{3}$ contained more $\mathrm{TTeC}$ and, at the same time, showed a greater anti-proliferative effect compared to the Hex fraction. This result is in accordance with other in vitro and in vivo studies that reported terpenoids as inhibitors of both cell proliferation and tumor growth in several tumors, including breast, prostate, pancreatic carcinomas, lung cancer, and leukemia [24,50-53]. Furthermore, in a recent work, the cytotoxic activity of different Azorellane diterpenoids isolated from A. compacta on a breast cancer cell line (MCF-7) was described [54]. However, more studies are needed to investigate potential anti-proliferative effects of terpenoids in MM.

Interestingly, we observed an anti-proliferative effect of $\mathrm{AG} \mathrm{CHCl}_{3}$ on three $\mathrm{MM}$ cell lines that harbor different chromosomal translocations $[t(16 ; 22), t(14 ; 20)$ and $t(14 ; 16)$ for RPMI8226, SKMM1, and MM1S, respectively]. In particular, the translocation, $t(14 ; 16)$, represents a high-risk cytogenetic marker [55]. Our data agree with previous studies that described the cytotoxic activity on solid and haematological malignancies of other Azorella extracts. Sung et al. reported the cytotoxic activity of methanolic extract of $A$. compacta and its ability to induce apoptosis on leukemic HL60 cells [34]. Previously, another work described the antiproliferative activity of a new chalcone from Azorella madreporica on colon, breast, and prostate cancer cells [56]. All these data indicate the Azorella genus as a possible source of natural agent against different cancer types, including hematologic malignancies.

The main criterion for an "ideal" anti-tumor agent is the specificity of the action on tumor cells, with no or minimal toxicity on healthy ones. For this reason, in addition to efficacy, the safety profile for the development of a new anti-tumor agent should be taken into consideration. To our knowledge, few studies have verified plant extracts' toxicity on healthy cells in a preliminary step. Interestingly, in the present work, we showed that $\mathrm{AG} \mathrm{CHCl}_{3}$ fraction did not show toxicity towards the normal cells, like PBMCs.

Wong et al. reported that $\mathrm{EC}_{50}$ values are widely used to assess the potency of a compound [57]. Our data indicated that the $\mathrm{EC}_{50}$ value was reduced over the time in all the MM cells, with a mean of $22.06 \pm 15.56 \mu \mathrm{g} / \mathrm{mL}$ after $72 \mathrm{~h}$ of treatment. These data are in agreement with a report demonstrating that a natural extract possessing an $\mathrm{EC}_{50}$ value of about $20 \mu \mathrm{g} / \mathrm{mL}$ is considered to have anti-cancer therapeutic value [58]. Thus, the fact that our $\mathrm{AG} \mathrm{CHCl}_{3}$ fraction showed an $\mathrm{EC}_{50}$ value around $20 \mu \mathrm{g} / \mathrm{mL}$ encourages further investigation for its possible therapeutic application.

Another essential characteristic of an antitumor drug is the ability to induce tumor cell apoptosis. In fact, the simultaneous ability of a substance to inhibit cell growth and to induce apoptosis allows discrimination between anti-tumor agents and toxic ones [34]. Our data showed a significant increase of apoptotic cells during treatment with the $\mathrm{AG} \mathrm{CHCl}_{3}$ fraction. Several works have demonstrated that the block in the G0/G1 phase is a characteristic feature of apoptosis [59-62]. Our data showed an increase of treated cells in the G0/G1 phase in a time dependent manner, with a corresponding decline of cells in the $\mathrm{S}$ and $\mathrm{G} 2 / \mathrm{M}$ phases, confirming apoptosis. In addition, the $\mathrm{AG} \mathrm{CHCl}_{3}$ fraction induced a strong inhibition of migration in myeloma cells, however, apoptosis was promoted.

Furthermore, to get a preliminary indication of the cellular mechanisms by which the $\mathrm{AG} \mathrm{CHCl}_{3}$ fraction induced cell death, the expression level of apoptosis-related proteins was detected by western blot analysis. AG $\mathrm{CHCl}_{3}$ fraction-treated cells showed an increase of PARP-1 cleavage, but no reduction 
of Bcl-2 protein levels were observed. These results indicated that, probably, the death process was not regulated through a mitochondrial damaged characteristic of the intrinsic pathway. In fact, both the extrinsic and intrinsic apoptotic pathways may be involved in caspase-3 cleavage [63], but Bcl-2 is implicated only in the intrinsic pathways. Bcl-2 blocks the release of cytochrome $c$ from the mitochondria into the cytosol [64], inhibiting changes in mitochondrial membrane potential and mitochondrial permeability [65].

Accumulation of ROS and the disruption of $\Delta \Psi_{\mathrm{m}}$ represents an early event in the intrinsic pathway of apoptosis [66]. In our setting, the $\mathrm{AG} \mathrm{CHCl}_{3}$ fraction did not significantly stimulate $\mathrm{ROS}$ formation in treated MM cells as compared with the control. ROS concentration was also not reduced. These results were the same that have been shown using in vitro assays in which we did not observe a strong radical scavenging activity of the $\mathrm{AG} \mathrm{CHCl}_{3}$ fraction. In addition, no loss of $\Delta \Psi_{\mathrm{m}}$ was detected in $\mathrm{MM}$ cells treated with the $\mathrm{AG} \mathrm{CHCl}_{3}$ fraction, pointing out that $\mathrm{AG} \mathrm{CHCl}_{3}$ fraction-induced apoptosis could not be regulated through mitochondrial damage.

In summary, our data strongly shows that $\mathrm{AG} \mathrm{CHCl}_{3}$ fraction has in vitro potential with anti-MM effects compared to HD-PBMCs, giving an additional advantage over other fractions. Considering the lack of literature knowledge on the anticancer effects of AG samples, this study represents pioneering research in this area. Further investigations are ongoing to (i) identify specific bioactive compounds; (ii) investigate the molecular mechanisms underlying anticancer activity; and (iii) define how these natural extracts could be used as a complementary approach to current therapies for MM. Altogether, our data indicate that AG samples could represent a promising source of natural anti-MM compounds.

\section{Materials and Methods}

\subsection{Chemicals and Reagents}

Fetal bovine serum (FBS), RPMI 1640, phosphate-buffered saline (PBS), and penicillin/streptomycin were purchased from Gibco-BRL (Life technologies, Carlsbad, CA, USA).

Solvents as ethanol, $n$-hexane, chloroform, ethyl acetate, $n$-butanol, methanol, sulfuric acid, and hydrochloric acid were purchased from Carlo Erba (Milano-Italy).

Folin-Ciocalteu reagent $2 \mathrm{~N}$, sodium carbonate, sodium nitrate, aluminum chloride, sodium hydroxide, 2.2'-azino-bis (3-ethylbenzothiazoline-6-sulfonic acid) (ABTS), dimethyl sulfoxide (DMSO), potassium persulfate, potassium phosphate monobasic, $\beta$-nicotinamide adenine dinucleotide reduced form (NADH), phenazinemethosulfate (PMS), nitrotetrazolium blue chloride (NBT), sodium nitroprusside dehydrate (SNP), sulfanilamide, N-(1-Naphthyl) ethylenediaminedihydrochloride, sodium acetate trihydrate, 2', $7^{\prime}$-dichlorodihydrofluorescein diacetate (DCFH-DA), Tris (hydroxymethyl) aminomethane (Tris),sodium chloride, tergitol ${ }^{\mathrm{TM}}$ solution (NP40), sodium dodecyl sulfate (SDS), NFM, TBST, sodium deoxycholateand standards as gallic acid, quercetin, linalool, 6-hydroxy-2.5.7.8tetramethylchroman-2-carboxylic acid (Trolox), and anti-rabbit secondary antibody were purchased from Sigma-Aldrich (Milano, Italy).

A cellTiter 96 Aqueous One Solution assay kit (MTS) was purchased from Promega (Madison, WI, USA).

Nitrocellulose membrane was purchased from GE Healthcare (Chicago, IL, USA).

A FITC Annexin V Apoptosis Detection kit was purchased from Becton Dickinson (BD Pharmingen, San Jose, CA, USA).

24-well Millicell Hanging cell culture transwell inserts $8 \mu \mathrm{m}$ PET (Millipore Corporation, Billerica, MA, USA).

TMRM (Life Technologies, Carlsbad, CA, USA) was a kind gift from Dr. M. Lasorsa (IBBE, CNR, Bari).

Antibody anti-PARP-1 was purchased from CST (Danvers, MA, USA).

Antibody anti-Bcl-2 and chemiluminescence (ECL plus) kit were purchased from Thermo Fisher (Rodano, Milano, Italy). 


\subsection{Preparation of AG Samples}

The AG aerial parts were collected in Bolivia near the Aymaya population/community $\left(18.45^{\circ} \mathrm{S}\right.$ to $66.46^{\circ} \mathrm{W} ; 3750 \mathrm{msnm}$ ), Bustillo province, Potosí department, Bolivia. Samples of the species are found in the herbal medicinal plants of the National University Siglo XX, Llallagua, Potosí, Bolivia.

A voucher specimen was stored at the University of La Paz, dried at room temperature, crushed, and extracted by dynamic maceration with $96 \% \mathrm{EtOH}$ (solid to solvent ratio of 1:10 w/v). The EtOH extract was filtrated through a $0.45 \mu \mathrm{m}$ Buchner funnel and dried by a rotary evaporator. Then, $22.00 \mathrm{~g}$ of EtOH extract were solved in $220 \mathrm{~mL}$ of distilled $\mathrm{H}_{2} \mathrm{O}$ and subjected to liquid/liquid extraction with $n$-hexane, chloroform, ethyl acetate, and $n$-butanol solvents to make a chemical compound separation.

\subsection{Healthy Donors, MM Cell Lines and Chemicals}

Five healthy subjects gave informed consent. Peripheral blood was drawn into EDTA tubes and PBMCs were collected by Ficoll-hypaque gradient separation. MM cell lines, SKMM1, RPMI8226, and MM1S, were purchased from American Type Culture Collection (ATCC) and cultured in RPMI 1640 supplemented with $10 \% \mathrm{FBS}$ and $1 \%$ of penicillin/streptomycin. All cell lines were grown at $37^{\circ} \mathrm{C}$ in $5 \% \mathrm{CO}_{2}$. All AG samples were dissolved in DMSO at the stock solution of $30 \mathrm{mg} / \mathrm{mL}$ and then diluted in FBS for cell treatments. The final DMSO concentration in the cultures was no greater than $0.5 \%$.

\subsection{Total Polyphenol Content (TPC), Total Flavonoid Content (TFC), and Total Terpenoid Content (TTeC)}

The dried crude $\mathrm{EtOH}$ extract and $\mathrm{Hex}, \mathrm{CHCl}_{3}, \mathrm{EtAc}$, and $\mathrm{BuOH}$ and $\mathrm{H}_{2} \mathrm{O}$ fractions were tested for their TPC, TFC, and TTeC content. The Folin-Ciocalteu assay as reported by Todaro et al. (2017) with slight modifications was used to determine the TPC content of AG samples [67]. The results were expressed as mg of gallic acid equivalents per gram of dried sample (mg GAE/g).

The TFC was determined using a solution with $5 \% \mathrm{NaNO}_{3}, 1 \% \mathrm{AlCl}_{3}$, and $1 \mathrm{M} \mathrm{NaOH}$ solution [38]. The results were expressed as mg of quercetin equivalents per gram of dried sample (mg QE/g) after the absorbance measurement at $510 \mathrm{~nm}$.

The evaluation of $\mathrm{TTeC}$ was performed by a rapid and high-throughput assay using the monoterpene linalool as the standard reagent. The absorbance was measured at $538 \mathrm{~nm}$ and the results were expressed as $\mathrm{mg}$ of linalool equivalents per gram of dried sample (mg LE/g).

\subsection{Radical-Scavenging Activity}

The antioxidant activity of AG samples was tested by three different in vitro antioxidant tests. In particular, we determined the radical scavenging activity by synthetic ABTS assay and physiological superoxide anion $(\mathrm{SO})$ and nitric oxide $(\mathrm{NO})$ radicals. The synthetic $\mathrm{ABTS}^{+}$radical and the biological $\mathrm{SO}$ and $\mathrm{NO}$ radicals were generated in different experiments and the capacity of the samples to scavenge these radicals was monitored by spectrophotometer (SPECTROstar ${ }^{\text {Nano }}$, BMG Labtech) $[68,69]$.

\subsubsection{ABTS Assay}

The 2.2'-azinobis-(3-ethylbenzothiazoline-6-sulfonic acid) diammonium salt (ABTS) radical assay was used to determine the radical-scavenging capacity of AG samples [70] against the $\mathrm{ABTS}^{+}{ }^{+}$radical.

\subsubsection{Super Oxide (SO) Anion Scavenging Activity}

The inhibition of formazan formation from samples was monitored at $560 \mathrm{~nm}$ and the results were expressed as the concentration inhibiting $25 \%$ of radical inhibition in $\mathrm{mg} / \mathrm{mL}\left(\mathrm{IC}_{25}\right)$. The ascorbic acid was used as the positive control [38]. 


\subsubsection{Nitric Oxide (NO) Radical Scavenging Activity}

The nitric oxide interacts with oxygen to give nitrite ions that can be determined spectrophotometrically by Griess reagent [38]. Results were expressed as $\mathrm{IC}_{25}$ of radical inhibition in $\mathrm{mg} / \mathrm{mL}$ and ascorbic acid was used as the positive control.

\subsection{Cell Viability Assay}

Cell viability was assessed using the MTS assay [71,72]. In brief, cells were seeded into 96-well plates $\left(3 \times 10^{4}\right.$ cell $/ 100 \mu \mathrm{L}$ medium), treated with AG samples at different concentrations $(10,50,100$, and $150 \mu \mathrm{g} / \mathrm{mL}$ ), and incubated for 24, 48, and $72 \mathrm{~h}$. The optical density was measured at $492 \mathrm{~nm}$. All experiments were conducted in triplicate. Cell viability was calculated as the percentage of $\mathrm{MM}$ viable cells in AG vs DMSO treated cells. The EC $_{50}$ was determined by GraphPad Prism (GraphPad Prism, San Diego, CA, USA).

\subsection{Apoptosis Assay}

Apoptotic cells were detected by cytometric analysis using a FITC Annexin V Apoptosis Detection kit (BD Pharmingen), according to the manufacturer's protocol. Briefly, MM cells were plated in a 6-well culture plate at a density of $4 \times 10^{5}$ cell/well, treated with $50 \mu \mathrm{g} / \mathrm{mL}$ of $\mathrm{AG} \mathrm{CHCl}_{3}$ fraction, and incubated for 24 and $48 \mathrm{~h}$. After treatment, cells were harvested, washed, and resuspended in Annexin V binding buffer [73]. Next, cells were labeled with $5 \mu \mathrm{L}$ of FITC Annexin V and $5 \mu \mathrm{L}$ of propidium iodide (PI). Stained cells were incubated at dark for $15 \mathrm{~min} .1 \times 10^{4}$ events were acquired using a NAVIOS flow cytometer and analyzed by Kaluza 2.0 software (Beckman Coulter, Life Sciences, Indianapolis, IN, USA). Both single positive for Annexin V and double positive for Annexin V and PI cells were interpreted as signs of early and late phases of apoptosis, respectively.

\subsection{Cell Cycle Analysis}

After treatment with $50 \mu \mathrm{g} / \mathrm{mL}$ of $\mathrm{AG} \mathrm{CHCl}_{3}$ fraction for 24 and $48 \mathrm{~h}$, MM cells were harvested, washed, and fixed in cold ethanol $70 \%$ for $1 \mathrm{~h}$. Fixed cells were then labeled with PI/RNase staining solution for $30 \mathrm{~min}$ at room temperature in the dark [73,74]. A total of $1 \times 10^{4}$ events were acquired by NAVIOS flow cytometer and analyzed by Kaluza 2.0 software (Beckman Coulter, Life Sciences, Indianapolis, IN, USA).

\subsection{Cell Migration Assays}

Transwell inserts with $8 \mu \mathrm{m}$ pores were inserted into a 24-well plates for migration studies. $1 \times 10^{5}$ RPMI8226 cells treated with $50 \mu \mathrm{g} / \mathrm{mL}$ of $\mathrm{AG} \mathrm{CHCl}_{3}$ fraction and with DMSO control were seeded into the inserts in $300 \mu \mathrm{L}$ of serum-free RPMI 1640 medium. $500 \mu \mathrm{L}$ of RPMI 1640 medium with $10 \%$ FBS were placed in the single well of a 24 well plate. After $24 \mathrm{~h}$ of incubation, cells that migrated into the lower chamber were counted. Triplicates of each experiment were performed.

\subsection{Measurement of Reactive Oxygen Species (ROS) Generation and of Mitochondrial Membrane Potential $\left(\Delta \Psi_{m}\right)$}

$2.5 \times 10^{5} \mathrm{RPMI} 8226$ cells were treated with $50 \mu \mathrm{g} / \mathrm{mL}$ of $\mathrm{AG} \mathrm{CHCl}_{3}$ fraction for $6 \mathrm{~h}$ and used to measure ROS and $\Delta \Psi_{\mathrm{m}}$ values, as reported in the following paragraphs.

\subsubsection{ROS Generation}

The level of intracellular ROS was determined following the method reported in Armentano et al. (2015) with slight modification [70]. Briefly, RPMI8226 cells were stained with $10 \mu \mathrm{M}$ of DCFH-DA and incubated for $30 \mathrm{~min}$ at $37^{\circ} \mathrm{C}$ in the dark. The fluorescence was measured by FACSCanto II flow cytometer and data were analyzed by DIVA software (BD Biosciences, San Jose, CA, USA). 


\subsection{2. $\Delta \Psi_{\mathrm{m}}$ Measurement}

The level of $\Delta \Psi_{\mathrm{m}}$ was monitored by flow cytometry as reported by Armentano et al. (2015) [70]. In brief, cells were incubated with $150 \mathrm{nM}$ of TMRM in PBS for $20 \mathrm{~min}$ at $37^{\circ} \mathrm{C}$ in the dark. Then, cells were analysed by FACSCanto II flow cytometer and data were analyzed by DIVA software.

\subsection{Western Blot Analysis}

A total of $2 \times 10^{6}$ of untreated, DMSO, and $50 \mu \mathrm{g} / \mathrm{mL}$ of $\mathrm{AG} \mathrm{CHCl}_{3}$-treated RPMI8226 cells were collected and lysed in buffer (50 mM Tris pH 7.4, $150 \mathrm{mMNaCl}, 1 \% \mathrm{NP} 40,0.1 \%$ SDS, $0.5 \%$ sodium deoxycholate) supplemented with protease inhibitors cocktail (Sigma Aldrich, Milano, Italy), followed by centrifugation at $13,000 \times g$ for $30 \mathrm{~min}$ at $4{ }^{\circ} \mathrm{C}$. The protein concentration in each sample was detected using the Bradford assay. Equal amounts of sample lysate $(80 \mu \mathrm{g})$ were separated by SDS-PAGE $(4-8 \%$ for PARP and $4-15 \%$ for $\mathrm{Bcl} 2$ ) and transferred to nitrocellulose membrane. Nonspecific binding sites were blocked with TBST buffer containing 5\% nonfat dry milk (NFM) at room temperature for $1 \mathrm{~h}$. Subsequently, membranes were incubated with primary antibodies anti-PARP-1 (1:1000 in 5\% NFM/TBST) and anti-Bcl-2 (1:200 in 5\% NFM/TBST) overnight at $4{ }^{\circ} \mathrm{C}$. After incubation with HRP-conjugated anti-rabbit secondary antibody $(1: 10,000)$, detection was performed using the enhanced chemiluminescence (ECL plus) kit.

\subsection{Statistical Analysis}

All data were expressed as mean \pm standard deviation or mean \pm standard error of mean of three independent experiments. To verify the correlation among the used methods, the $p$ values were analysed by one-way analysis of variance (ANOVA); a Pearson coefficient and $T$-test were determined using GraphPad Prism 5 Software (San Diego, CA, USA).

Author Contributions: Conceptualization: D.L., L.M. and A.C.; Data curation: D.L., I.F., I.L., L.M. and M.F.A.; Formal analysis: I.L., L.M. and L.C.; Methodology: D.L., I.F., I.L., L.M., S.T., L.D.L., M.F.A., C.S., L.C. and D.R.; Supervision: L.D.V., P.M. and A.C.; Writing—original draft: D.L. and I.F.; Writing—review \& editing: F.B., P.M. and A.C.

Funding: This research was funded by Italian Minister of Health—Ricerca corrente 2017.

Acknowledgments: It is with great sadness and profound sense of loss that all co-authors remember the passing of Prof. Luigi Del Vecchio (16 August 2018), a long-time collaborator, an irreplaceable colleague and a wonderful person. This paper is dedicated to him.

Conflicts of Interest: The authors declare no conflict of interest.

\section{References}

1. Soekojo, C.; de Mel, S.; Ooi, M.; Yan, B.; Chng, W. Potential Clinical Application of Genomics in Multiple Myeloma. Int. J. Mol. Sci. 2018, 19, 1721. [CrossRef] [PubMed]

2. Issa, M.; Cretton, S.; Cuendet, M. Targeting Multiple Myeloma Cancer Stem Cells with Natural ProductsLessons from Other Hematological Malignancies. Planta Med. 2017, 83, 752-760. [CrossRef] [PubMed]

3. Fonseca, R.; Abouzaid, S.; Bonafede, M.; Cai, Q.; Parikh, K.; Cosler, L.; Richardson, P. Trends in overall survival and costs of multiple myeloma, 2000-2014. Leukemia 2017, 31, 1915-1921. [CrossRef] [PubMed]

4. Turesson, I.; Bjorkholm, M.; Blimark, C.H.; Kristinsson, S.; Velez, R.; Landgren, O. Rapidly changing myeloma epidemiology in the general population: Increased incidence, older patients, and longer survival. Eur. J. Haematol. 2018, 101, 237-244. [CrossRef] [PubMed]

5. Manier, S.; Salem, K.Z.; Park, J.; Landau, D.A.; Getz, G.; Ghobrial, I.M. Genomic complexity of multiple myeloma and its clinical implications. Nat. Rev. Clin. Oncol. 2017, 14, 100-113. [CrossRef] [PubMed]

6. Palumbo, A.; Chanan-Khan, A.; Weisel, K.; Nooka, A.K.; Masszi, T.; Beksac, M.; Spicka, I.; Hungria, V.; Munder, M.; Mateos, M.V.; et al. Daratumumab, Bortezomib, and Dexamethasone for Multiple Myeloma. N. Engl. J. Med. 2016, 375, 754-766. [CrossRef] [PubMed]

7. Rajan, A.M.; Kumar, S. New investigational drugs with single-agent activity in multiple myeloma. Blood Cancer J. 2016, 6, e451. [CrossRef] [PubMed] 
8. Cho, S.-F.; Lin, L.; Xing, L.; Yu, T.; Wen, K.; Anderson, K.C.; Tai, Y.-T. Monoclonal Antibody: A New Treatment Strategy against Multiple Myeloma. Antibodies 2017, 6, 18. [CrossRef]

9. Sherbenou, D.W.; Mark, T.M.; Forsberg, P. Monoclonal Antibodies in Multiple Myeloma: A New Wave of the Future. Clin. Lymphoma Myeloma Leuk. 2017, 17, 545-554. [CrossRef] [PubMed]

10. Kocoglu, M.; Badros, A. The role of immunotherapy in multiple myeloma. Pharmaceuticals 2016, 9, 3. [CrossRef] [PubMed]

11. Gay, F.; Engelhardt, M.; Terpos, E.; Wäsch, R.; Giaccone, L.; Auner, H.W.; Caers, J.; Gramatzki, M.; Van De Donk, N.; Oliva, S.; et al. From transplant to novel cellular therapies in multiple myeloma: European myeloma network guidelines and future perspectives. Haematologica 2018, 103, 197-211. [CrossRef] [PubMed]

12. Issa, M.E.; Takhsha, F.S.; Chirumamilla, C.S.; Perez-Novo, C.; Vanden Berghe, W.; Cuendet, M. Epigenetic strategies to reverse drug resistance in heterogeneous multiple myeloma. Clin. Epigenet. 2017, 9, 17. [CrossRef] [PubMed]

13. Kumar, S.K.; Dispenzieri, A.; Lacy, M.Q.; Gertz, M.A.; Buadi, F.K.; Pandey, S.; Kapoor, P.; Dingli, D.; Hayman, S.R.; Leung, N.; et al. Continued improvement in survival in multiple myeloma: Changes in early mortality and outcomes in older patients. Leukemia 2014, 28, 1122-1128. [CrossRef] [PubMed]

14. Kumar, S.K.; Rajkumar, V.; Kyle, R.A.; Van Duin, M.; Sonneveld, P.; Mateos, M.V.; Gay, F.; Anderson, K.C. Multiple myeloma. Nat. Rev. Dis. Prim. 2017, 3, 17046. [CrossRef] [PubMed]

15. Caivano, A.; La Rocca, F.; Laurenzana, I.; Annese, T.; Tamma, R.; Famigliari, U.; Simeon, V.; Trino, S.; De Luca, L.; Villani, O.; et al. Epha3 acts as proangiogenic factor in multiple myeloma. Oncotarget 2017, 8, 34298-34309. [CrossRef] [PubMed]

16. La Rocca, F.; Airoldi, I.; Di Carlo, E.; Marotta, P.; Falco, G.; Simeon, V.; Laurenzana, I.; Trino, S.; De Luca, L.; Todoerti, K.; et al. EphA3 targeting reduces in vitro adhesion and invasion and in vivo growth and angiogenesis of multiple myeloma cells. Cell. Oncol. 2017, 40, 483-496. [CrossRef] [PubMed]

17. Kumar, G.; Mittal, S.; Sak, K.; Tuli, H.S. Molecular mechanisms underlying chemopreventive potential of curcumin: Current challenges and future perspectives. Life Sci. 2016, 148, 313-328. [CrossRef] [PubMed]

18. Chen, J.; Li, L.; Su, J.; Li, B.; Chen, T.; Wong, Y.S. Synergistic apoptosis-inducing effects on A375 human melanoma cells of natural borneol and curcumin. PLoS ONE 2014, 9, e101277. [CrossRef] [PubMed]

19. Cho, J.; Rho, O.; Junco, J.; Carbajal, S.; Siegel, D.; Slaga, T.J.; DiGiovanni, J. Effect of Combined Treatment with Ursolic Acid and Resveratrol on Skin Tumor Promotion by 12-O-Tetradecanoylphorbol-13-Acetate. Cancer Prev. Res. 2015, 8, 817-825. [CrossRef] [PubMed]

20. Kiraz, Y.; Neergheen-Bhujun, V.S.; Rummun, N.; Baran, Y. Apoptotic effects of non-edible parts of Punica granatum on human multiple myeloma cells. Tumor Biol. 2016, 37, 1803-1815. [CrossRef] [PubMed]

21. Estrela, J.M.; Mena, S.; Obrador, E.; Benlloch, M.; Castellano, G.; Salvador, R.; Dellinger, R.W. Polyphenolic Phytochemicals in Cancer Prevention and Therapy: Bioavailability versus Bioefficacy. J. Med. Chem. 2017, 60, 9413-9436. [CrossRef] [PubMed]

22. Kou, X.; Han, L.; Li, X.; Xue, Z.; Zhou, F. Antioxidant and antitumor effects and immunomodulatory activities of crude and purified polyphenol extract from blueberries. Front. Chem. Sci. Eng. 2016, 10, 108-119. [CrossRef]

23. Romano, B.; Pagano, E.; Montanaro, V.; Fortunato, A.L.; Milic, N.; Borrelli, F. Novel insights into the pharmacology of flavonoids. Phyther. Res. 2013, 27, 1588-1596. [CrossRef] [PubMed]

24. Adnan, M.; Patel, M.; Reddy, M.N.; Alshammari, E. Formulation, evaluation and bioactive potential of Xylaria primorskensis terpenoid nanoparticles from its major compound xylaranic acid. Sci. Rep. 2018, 8, 1740. [CrossRef] [PubMed]

25. Cheng, Y.T.; Yang, C.C.; Shyur, L.F. Phytomedicine-Modulating oxidative stress and the tumor microenvironment for cancer therapy. Pharmacol. Res. 2016, 114, 128-143. [CrossRef] [PubMed]

26. Efferth, T. Cancer combination therapies with artemisinin-type drugs. Biochem. Pharmacol. 2017, 139, 56-70. [CrossRef] [PubMed]

27. Mann, J. Natural products in cancer chemotherapy: Past, present and future. Nat. Rev. Cancer 2002, 2, 143-148. [CrossRef] [PubMed]

28. Cragg, G.M.; Newman, D.J. Plants as a source of anti-cancer agents. J. Ethnopharmacol. 2005, 100, 72-79. [CrossRef] [PubMed]

29. Siveen, K.S.; Uddin, S.; Mohammad, R.M. Targeting acute myeloid leukemia stem cell signaling by natural products. Mol. Cancer 2017, 16, 13. [CrossRef] [PubMed] 
30. Frost, B.M.; Lönnerholm, G.; Koopmans, P.; Abrahamsson, J.; Behrendtz, M.; Castor, A.; Forestier, E.; Uges, D.R.A.; De Graaf, S.S.N. Vincristine in childhood leukaemia: No pharmacokinetic rationale for dose reduction in adolescents. Acta Paediatr. Int. J. Paediatr. 2003, 92, 551-557. [CrossRef]

31. Okouneva, T.; Hill, B.T.; Wilson, L.; Jordan, M.A. The effects of vinflunine, vinorelbine, and vinblastine on centromere dynamics. Mol. Cancer Ther. 2003, 2, 427-436. [PubMed]

32. Bahmani, F.; Esmaeili, S.; Bashash, D.; Dehghan-Nayeri, N.; Mashati, P.; Gharehbaghian, A. Centaurea albonitens extract enhances the therapeutic effects of Vincristine in leukemic cells by inducing apoptosis. Biomed. Pharmacother. 2018, 99, 598-607. [CrossRef] [PubMed]

33. Kabeel, M.M.; Ghoneim, A.M.; Mansy, S.E. Anti-leukemic activity of a four-plant mixture in a leukemic rat model. J. Basic Appl. Zool. 2018, 79, 7. [CrossRef]

34. Sung, M.H.; Kwon, O.-K.; Oh, S.-R.; Lee, J.; Park, S.-H.; Han, S.B.; Ahn, K.-S. Azorella compacta methanolic extract induces apoptosis via activation of mitogen-activated protein kinase. Mol. Med. Rep. 2015, 12, 6821-6828. [CrossRef] [PubMed]

35. Shammas, M.A.; Neri, P.; Koley, H.; Batchu, R.B.; Bertheau, R.C.; Munshi, V.; Prabhala, R.; Fulciniti, M.; Tai, Y.T.; Treon, S.P.; et al. Specific killing of multiple myeloma cells by (-)-epigallocatechin-3-gallate extracted from green tea: Biologic activity and therapeutic implications. Blood 2006, 108, 2804-2810. [CrossRef] [PubMed]

36. Wang, H.; Yang, S.; Zhou, H.; Sun, M.; Du, L.; Wei, M.; Luo, M.; Huang, J.; Deng, H.; Feng, Y.; et al. Aloperine executes antitumor effects against multiple myeloma through dual apoptotic mechanisms. J. Hematol. Oncol. 2015, 8, 26. [CrossRef] [PubMed]

37. Plunkett, G.M.; Nicolas, A.N. Assessing Azorella (Apiaceae) and its allies: Phylogenetics and a new classification. Brittonia 2017, 69, 31-61. [CrossRef]

38. Russo, D.; Valentão, P.; Andrade, P.B.; Fernandez, E.C.; Milella, L. Evaluation of antioxidant, antidiabetic and anticholinesterase activities of smallanthus sonchifolius landraces and correlation with their phytochemical profiles. Int. J. Mol. Sci. 2015, 16, 17696-17718. [CrossRef] [PubMed]

39. Milella, L.; Bader, A.; De Tommasi, N.; Russo, D.; Braca, A. Antioxidant and free radical-scavenging activity of constituents from two Scorzonera species. Food Chem. 2014, 160, 298-304. [CrossRef] [PubMed]

40. Prinsloo, G.; Nogemane, N.; Street, R. The use of plants containing genotoxic carcinogens as foods and medicine. Food Chem. Toxicol. 2018, 116, 27-39. [CrossRef] [PubMed]

41. Newman, D.J.; Cragg, G.M. Natural Products as Sources of New Drugs from 1981 to 2014. J. Nat. Prod. 2016, 79, 629-661. [CrossRef] [PubMed]

42. Shanmugam, M.K.; Lee, J.H.; Chai, E.Z.P.; Kanchi, M.M.; Kar, S.; Arfuso, F.; Dharmarajan, A.; Kumar, A.P.; Ramar, P.S.; Looi, C.Y.; et al. Cancer prevention and therapy through the modulation of transcription factors by bioactive natural compounds. Semin. Cancer Biol. 2016, 40-41, 35-47. [CrossRef] [PubMed]

43. Shanmugam, M.K.; Kannaiyan, R.; Sethi, G. Targeting Cell Signaling and Apoptotic Pathways by Dietary Agents: Role in the Prevention and Treatment of Cancer. Nutr. Cancer 2011, 63, 161-173. [CrossRef] [PubMed]

44. Gulder, T.A.M.; Moore, B.S. Salinosporamide natural products: Potent $20 \mathrm{~S}$ proteasome inhibitors as promising cancer chemotherapeutics. Angew. Chem. Int. Ed. 2010, 49, 9346-9367. [CrossRef] [PubMed]

45. Caso, A.; Laurenzana, I.; Lamorte, D.; Trino, S.; Esposito, G.; Piccialli, V.; Costantino, V. Smenamide a analogues. Synthesis and biological activity on multiple myeloma cells. Mar. Drugs 2018, 16, 206. [CrossRef] [PubMed]

46. Nakamura, M.; Ra, J.H.; Jee, Y.; Kim, J.S. Impact of different partitioned solvents on chemical composition and bioavailability of Sasa quelpaertensis Nakai leaf extract. J. Food Drug Anal. 2017, 25, 316-326. [CrossRef] [PubMed]

47. Genovese, C.; Brundo, M.V.; Toscano, V.; Tibullo, D.; Puglisi, F.; Raccuia, S.A. Effect of Cynara extracts on multiple myeloma cell Lines. Acta Hortic. 2016, 1147, 113-118. [CrossRef]

48. Issa, M.E.; Berndt, S.; Carpentier, G.; Pezzuto, J.M.; Cuendet, M. Bruceantin inhibits multiple myeloma cancer stem cell proliferation. Cancer Biol. Ther. 2016, 17, 966-975. [CrossRef] [PubMed]

49. Neergheen, V.S.; Bahorun, T.; Taylor, E.W.; Jen, L.S.; Aruoma, O.I. Targeting specific cell signaling transduction pathways by dietary and medicinal phytochemicals in cancer chemoprevention. Toxicology 2010, 278, 229-241. [CrossRef] [PubMed]

50. Yang, H.; Dou, Q.P. Targeting Apoptosis Pathway with Natural Terpenoids: Implications for Treatment of Breast and Prostate Cancer. Curr. Drug Targets 2010, 11, 733-744. [CrossRef] [PubMed] 
51. Kapoor, S. Triptolide and management of systemic malignancies besides pancreatic carcinomas. World J. Gastroenterol. 2009, 15, 1018-1019. [CrossRef] [PubMed]

52. Molnár, J.; Gyémánt, N.; Mucsi, I.; Molnár, A.; Szabó, M.; Körtvélyesi, T.; Varga, A.; Molnár, P.; Tóth, G. Modulation of multidrug resistance and apoptosis of cancer cells by selected carotenoids. In Vivo 2004, 18, 237-244. [PubMed]

53. De Martino, L.; D'arena, G.; Filosa, R.; Peduto, A.; Zeppa, R.; De Feo, V. Natural Compounds in Anti-Leukaemic Therapy: A Review. Mini Rev. Med. Chem. 2011, 11, 492-502. [CrossRef] [PubMed]

54. Bórquez, J.; Bartolucci, N.L.; Echiburú-Chau, C.; Winterhalter, P.; Vallejos, J.; Jerz, G.; Simirgiotis, M.J. Isolation of cytotoxic diterpenoids from the Chilean medicinal plant Azorella compacta Phil from the Atacama Desert by high-speed counter-current chromatography. J. Sci. Food Agric. 2016, 96, 2832-2838. [CrossRef] [PubMed]

55. Paszekova, H.; Kryukov, F.; Kubiczkova, L.; Hajek, R.; Sevcikova, S. High-risk multiple myeloma: Different definitions, different outcomes? Clin. Lymphoma Myeloma Leuk. 2014, 14, 24-30. [CrossRef] [PubMed]

56. San-Martin, A.; Donoso, V.; Leiva, S.; Bacho, M.; Nunez, S.; Gutierrez, M.; Rovirosa, J.; Bailon-Moscoso, N.; Cuenca Camacho, S.; Malagon Aviles, O.; et al. Molecular Docking Studies of the Antitumoral Activity and Characterization of New Chalcone. Curr. Top. Med. Chem. 2015, 15, 1743-1749. [CrossRef] [PubMed]

57. Wong, F.C.; Woo, C.C.; Hsu, A.; Tan, B.K.H. The Anti-Cancer Activities of Vernonia amygdalina Extract in Human Breast Cancer Cell Lines Are Mediated through Caspase-Dependent and p53-Independent Pathways. PLoS ONE 2013, 8, e78021. [CrossRef] [PubMed]

58. Da Rocha, A.B.; Lopes, R.M.; Schwartsmann, G. Natural products in anticancer therapy. Curr. Opin. Pharmacol. 2001, 1, 364-369. [CrossRef]

59. Bertoli, C.; Skotheim, J.M.; De Bruin, R.A.M. Control of cell cycle transcription during G1 and S phases. Nat. Rev. Mol. Cell Biol. 2013, 14, 518-528. [CrossRef] [PubMed]

60. Park, S.; Bazer, F.W.; Lim, W.; Song, G. The O-methylated isoflavone, formononetin, inhibits human ovarian cancer cell proliferation by sub G0/G1 cell phase arrest through PI3K/AKT and ERK1/2 inactivation. J. Cell. Biochem. 2018, 119, 7377-7387. [CrossRef] [PubMed]

61. Yang, L.F.; Liu, H.R.; Long, M.; Wang, X.; Lin, F.; Gao, Z.W.; Zhang, H.Z. Peptide SA12 inhibits proliferation of breast cancer cell lines MCF-7 and MDA-MB-231 through G0/G1 phase cell cycle arrest. Onco Targets Ther. 2018, 11, 2409-2417. [CrossRef] [PubMed]

62. Wu, X.; Song, M.; Qiu, P.; Li, F.; Wang, M.; Zheng, J.; Wang, Q.; Xu, F.; Xiao, H. A metabolite of nobiletin, $4^{\prime}$-demethylnobiletin and atorvastatin synergistically inhibits human colon cancer cell growth by inducing G0/G1 cell cycle arrest and apoptosis. Food Funct. 2018, 9, 87-95. [CrossRef] [PubMed]

63. Fatehchand, K.; Santhanam, R.; Shen, B.; Erickson, E.L.; Gautam, S.; Elavazhagan, S.; Mo, X.; Belay, T.; Tridandapani, S.; Butchar, J.P. Active hexose-correlated compound enhances extrinsic-pathway-mediated apoptosis of Acute Myeloid Leukemic cells. PLoS ONE 2017, 12, e0181729. [CrossRef] [PubMed]

64. Edlich, F.; Martinou, J.-C. Bcl-2 Protein Interplay on the Outer Mitochondrial Membrane. In Mitochondira and Cell Death; Humana Press: New York, NY, USA, 2016; pp. 69-83.

65. Giorgio, V.; Guo, L.; Bassot, C.; Petronilli, V.; Bernardi, P. Calcium and regulation of the mitochondrial permeability transition. Cell Calcium 2017, 70, 56-63. [CrossRef] [PubMed]

66. Russo, D.; Miglionico, R.; Carmosino, M.; Bisaccia, F.; Andrade, P.B.; Valentão, P.; Milella, L.; Armentano, M.F. A comparative study on phytochemical profiles and biological activities of Sclerocarya birrea (A.Rich.) hochst leaf and bark extracts. Int. J. Mol. Sci. 2018, 19, 186. [CrossRef] [PubMed]

67. Todaro, L.; Russo, D.; Cetera, P.; Milella, L. Effects of thermo-vacuum treatment on secondary metabolite content and antioxidant activity of poplar (Populus nigra L.) wood extracts. Ind. Crops Prod. 2017, 109, 384-390. [CrossRef]

68. Fournet, A.; Barrios, A.A.; Muñoz, V. Leishmanicidal and trypanocidal activities of Bolivian medicinal plants. J. Ethnopharmacol. 1994, 41, 19-37. [CrossRef]

69. Dekdouk, N.; Malafronte, N.; Russo, D.; Faraone, I.; De Tommasi, N.; Ameddah, S.; Severino, L.; Milella, L. Phenolic Compounds from Olea europaea L. Possess Antioxidant Activity and Inhibit Carbohydrate Metabolizing Enzymes In Vitro. Evid.-Based Complement. Altern. Med. 2015, 2015, 684925. [CrossRef] [PubMed] 
70. Armentano, M.F.; Bisaccia, F.; Miglionico, R.; Russo, D.; Nolfi, N.; Carmosino, M.; Andrade, P.B.; Valentão, P.; Diop, M.S.; Milella, L. Antioxidant and proapoptotic activities of Sclerocarya birrea [(A. Rich.) Hochst.] methanolic root extract on the hepatocellular carcinoma cell line HepG2. Biomed. Res. Int. 2015, 2015, 561589. [CrossRef] [PubMed]

71. Laurenzana, I.; Caivano, A.; Trino, S.; De Luca, L.; La Rocca, F.; Simeon, V.; Tintori, C.; D'Alessio, F.; Teramo, A.; Zambello, R.; et al. A Pyrazolo[3,4-d]pyrimidine compound inhibits Fyn phosphorylation and induces apoptosis in natural killer cell leukemia. Oncotarget 2016, 7, 65171-65184. [CrossRef] [PubMed]

72. Laurenzana, I.; Caivano, A.; La Rocca, F.; Trino, S.; De Luca, L.; D'Alessio, F.; Schenone, S.; Falco, G.; Botta, M.; Del Vecchio, L.; et al. A pyrazolo[3,4-d]pyrimidine compound reduces cell viability and induces apoptosis in different hematological malignancies. Front. Pharmacol. 2016, 7, 416. [CrossRef] [PubMed]

73. Trino, S.; Iacobucci, I.; Erriquez, D.; Laurenzana, I.; De Luca, L.; Ferrari, A.; Ghelli Luserna Di Rorà, A.; Papayannidis, C.; Derenzini, E.; Simonetti, G.; et al. Targeting the p53-MDM2 interaction by the small-molecule MDM2 antagonist Nutlin-3a: A new challenged target therapy in adult Philadelphia positive acute lymphoblastic leukemia patients. Oncotarget 2016, 7, 12951-12961. [CrossRef] [PubMed]

74. Russo, D.; Malafronte, N.; Frescura, D.; Imbrenda, G.; Faraone, I.; Milella, L.; Fernandez, E.; De Tommasi, N. Antioxidant activities and quali-quantitative analysis of different Smallanthus sonchifolius [(Poepp. and Endl.) H. Robinson] landrace extracts. Nat. Prod. Res. 2015, 29, 1673-1677. [CrossRef] [PubMed]

(C) 2018 by the authors. Licensee MDPI, Basel, Switzerland. This article is an open access article distributed under the terms and conditions of the Creative Commons Attribution (CC BY) license (http://creativecommons.org/licenses/by/4.0/). 